\title{
The relationship between personality, self-esteem, emotional intelligence, and cultural intelligence. A military context
}

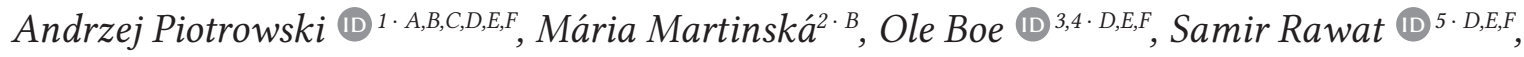 \\ Abhijit Deshpande (D) $5 \cdot D, E, F$
}

1: Institute of Psychology, University of Gdansk, Gdansk, Poland

2: Armed Forces Academy of General Milan Rastislav Štefánik, Liptovský Mikuláš, Slovakia

3: University of South-Eastern Norway, Kongsberg, Norway

4: Bjørknes University College, Oslo, Norway

5: Symbiosis International University, Pune, Maharashtra, India

\section{BACKGROUND}

An increasing number of migrants in almost all culturally homogeneous countries poses a significant societal challenge. The current research aims to explore the relationship of personality traits, self-esteem, and emotional intelligence with cultural intelligence.

\section{PARTICIPANTS AND PROCEDURE}

Five studies were carried out using the Cultural Intelligence Scale (CSQ) together with additional measures. In Study $1(N=145)$, participants from Slovakia $(n=74)$ and Poland $(n=71)$ completed the CSQ and the Mini International Personality Item Pool Scales. In Study $2(N=138)$ and $3(N=129)$, the participants completed the CSQ and selected subscales from the International Personality Item Pool - 16 Personality Factor Questionnaire. The CSQ and the Emotional Intelligence Questionnaire were used in Study $4(N=74)$; and the CSQ and the Rosenberg SelfEsteem Scale were used in Study $5(N=91)$.

\section{RESULTS}

Cultural intelligence was most strongly related to extraversion in the Slovak sample and with intellect in the Polish sample. A relationship of gregariousness, friendliness, and sensitivity, but not warmth, distrust, and reserve with the individual factors of cultural intelligence was also observed in the Polish sample. Emotional intelligence was related to the metacognitive, motivational, and behavioral factors of cultural intelligence, while self-esteem was related only to the motivational factor.

\section{CONCLUSIONS}

Personality traits are invariably related to individual factors of cultural intelligence. These relations assume varying patterns in Polish and Slovak individuals. Some factors of cultural intelligence are related to emotional intelligence and self-esteem. No differences were found in terms of cultural intelligence between cadets and civil students.

\section{KEY WORDS}

emotional intelligence; self-esteem; personality traits; cultural intelligence; cadets

Corresponding Author - Andrzej Piotrowski, Ph.D., Institute of Psychology, University of Gdansk, 4 Bażyńskiego Str., 80-952 Gdansk, Poland, e-mail: andrzej.piotrowski@ug.edu.pl

Authors' Contribution - A: Study design - B: Data collection - C: Statistical analysis - D: Data interpretation .

E: Manuscript preparation - F: Literature search · G: Funds collection

to Cite this ARTICle - Piotrowski, A., Martinská, M., Boe, O., Rawat, S., \& Deshpande, A. (2020). The relationship between personality, self-esteem, emotional intelligence, and cultural intelligence. A military context. Current Issues in Personality Psychology, 8(3), 185-196.

RECEIVED 05.06.2020 • REVIEWED 22.07.2020 • ACCEPTED 25.09.2020 • PUBLISHED 15.10.2020 


\section{BACKGROUND}

Interest in the higher-order personality factors of the Big Five model has remained high for years. This is due to the model's usefulness and the high stability of its proposed taxonomy. This taxonomy is consistently confirmed in studies on various professional, language, and cultural groups worldwide (Costa $\&$ McCrae, 1992). The Big Five model reliably predicts behavior in workplace, domestic, and cultural contexts (Barrick \& Mount, 1991). Widely accepted, the Big Five model also allows for systematic data collection and comparison on an international scale (Costa \& McCrae, 1995; McCrae \& Costa, 1995).

According to the evolutionary theory of personality, the Big Five personality traits represent universal mechanisms of adaptation to various physical, social, and cultural conditions (Buss, 1991; MacDonald, 1998). Personality traits serve as adaptative mechanisms which predispose individuals towards specific goaloriented behaviors in specific situations (Buss, 1991).

All individuals possess these universal and adaptive mechanisms, but to a varying extent. Individuals characterized by key personality traits suitable to their role in a specific physical or social environment will adapt more effectively than those whose personality traits are not suited to their environment and its demands.

Technological advances in communication and travel have resulted in greater contact between people from different cultures. Thus cultural competence in the context of job performance has become increasingly important, both for individuals and for entire social groups (even those not previously associated with multiculturalism, e.g., soldiers, Rockstuhl, Seiler, Ang, Van Dyne, \& Annen, 2011).

Cultural intelligence increases effectiveness of functioning in a multicultural environment both directly (i.e., in face-to-face contact) and indirectly (e.g., in computer-mediated contact, Presbitero, 2016). Earley (2002, see also Earley \& Ang, 2003) introduced a model of cultural intelligence (CQ) to explain differences in effectiveness of individual intercultural interactions. In this model, CQ is defined as a person's capability to successfully adapt to new cultural settings. It involves information acquisition and processing, decision making, and adapting to new environments. It is composed of four factors: metacognitive CQ, cognitive CQ, motivational CQ, and behavioral CQ (Earley \& Ang, 2003).

The metacognitive factor refers to an individual's cultural sensitivity or awareness during intercultural interactions (Ang \& Van Dyne, 2008). Cognitive CQ is acquired knowledge about similarities and differences between cultures in norms, practices, and conventions. Motivational CQ comprises an individual's ability to focus attention and energy in adapting to new cultural conditions. Individuals with high motivational CQ enjoy interacting with people from other cultures than their own and they feel confident in their competences. Finally, the behavioral factor describes an individual's repertoire of behavioral skills, both verbal and nonverbal, employed in new cultural contexts.

According to Shu, McAbee, and Ayman (2017), CQ and personality traits should be considered as complementary, though ultimately separate predictors of intercultural adaptation. Likewise, Li, Mobley, and Kelly (2016) claim that research on personality and CQ would benefit from an interactive approach and that the assessment and selection of employees for international organizations should consider their personality traits synthetically, not separately.

Ang, Dyne, and Koh (2006) hypothesized the relationship between the main personality traits and CQ. The Big Five model offers a theoretical framework for predicting the quality of intercultural interactions. A hierarchical regression analysis showed that agreeableness and openness to experience are the most important for the metacognitive CQ factor and that agreeableness, emotional stability, extraversion, and openness are the most important for the behavioral CQ factor. According to Ang et al. (2006), openness to experience is crucial during intercultural interactions. The results also show the varied relations between individual personality traits and CQ factors.

The research by Ang et al. (2006) points to a relationship between the main personality traits and CQ. Openness to experience correlated with cognitive, metacognitive, behavioral, and motivational CQ at a similar level (from .23 to .28). Extraversion correlated with metacognitive (.20) and motivational (.19) CQ. Stability correlated with metacognitive and motivational CQ at the same level (.18). No correlations between agreeableness and CQ factors were revealed. Finally, conscientiousness correlated with metacognitive (.16) and motivational (.27) CQ.

According to Depaula, Azzollini, Cosentino, and Castillo (2016), openness to experience might predict CQ better than extraversion and prior intercultural experiences (Depaula \& Azzolini, 2013). Training to increase CQ is possible, although the metacognitive and behavioral factors are easier to train in individuals with high extraversion, while the motivational factor is easier to train in individuals with high openness to experience (Şahin, Gurbuz, \& Köksal, 2014). Thus, personality might moderate the effectiveness of cultural training (Fischer, 2011).

Many studies point to the relationship between personality factors and emigrants' job performance. A meta-analysis carried out by Mol, Born, Willemsen, and Van Der Molen (2005) showed that personality factors were significantly related to emigrants' job efficiency. There is also evidence that personality factors influence multicultural adaptation (e.g., Peltokorpi, 2008; Shaffer, Harrison, Gregersen, Black, \& Ferzandi, 2006). Individuals with higher $C Q$ are characterized by good negotiation skills (Imai \& Gelfand, 2010), pas- 
sion for work (Sousa \& Gonçalves, 2017), and job satisfaction (Lie, Suyasa, \& Wijaya, 2016), especially in multicultural settings.

Research on emotional intelligence and its links with general social functioning has gained in popularity over the past few decades (Moroń, 2018). Individuals with high emotional intelligence cope well with everyday problems and have satisfying interpersonal relationships, including in the workplace (Mandal \& Latusek, 2018). To better manage social challenges, people must possess an ability to understand and use emotions (Szczygieł \& Weber, 2017). Thompson's (2018) research shows that emotional and cultural intelligence play an important role in international students' social integration.

The impact of emotional intelligence on employee creativity depends on CQ. High CQ employees can quickly adapt to their clients' or coworkers' cultures, which allows them to develop new ideas and initiate new activities (Darvishmotevali, Altinay, \& De Vita, 2018). Thus, possessing emotional intelligence, which facilitates recognizing and regulating one's own and others' emotions, together with CQ, which focuses both on emotions and on intercultural interactions, results in new ideas and creative activity (Sygit-Kowalkowska, Sygit, \& Sygit, 2015). Da Costa, Páez, Sánchez, Garaigordobil, and Gondim (2015) highlight that cognitive aspects such as CQ and emotional aspects such as emotional intelligence are more important for innovation in the workplace than motivational factors. Thus, it is important to consider CQ and emotional intelligence together in the context of recruitment for multicultural workplaces. For current employees, cultural and emotional intelligence can be developed through appropriate training. According to Lin, Chen, and Song (2012), emotional intelligence positively moderates the relationship between CQ and intercultural adaptation.

Rosenberg (1965) defines self-esteem as a positive or negative attitude towards the Self. High self-esteem involves satisfaction with oneself, and low self-esteem involves lack of acceptance of oneself. Rosenberg stated that high self-esteem is the belief of being a "good enough," valuable person. High self-esteem individuals do not necessarily believe they are superior to others. Self-esteem can refer to overall functioning (global self-esteem) or to specific domains of functioning (specific self-esteem). Individuals with high global self-esteem can hold differing opinions about their specific traits or competences, such as intelligence, attractiveness, or health (Piotrowski, 2018). The most popular model of self-esteem holds that global self-esteem influences specific self-esteem (Brown \& Dutton, 1997). In Rosenberg's account, self-esteem is conceptualized as a trait, that is, a relatively stable disposition (Heimpel, Wood, Marshall, \& Brown, 2002). However, self-esteem can be susceptible to changes. It can change both in the short- and long-term perspective in response to events and situational contexts.
Low self-esteem individuals more often display an aggression-based style of conflict resolution (Borecka-Biernat, 2014). However, the relationship between self-esteem and social functioning is ambiguous. Individuals with high and low self-esteem are equally wellliked by their peers (Bishop \& Inderbitzen, 1995). High self-esteem individuals perceive themselves as more socially attractive and better liked in their group (Battistisch, Solomon, \& Delucchi, 1993), while low selfesteem individuals report more negative social experiences (Lakey, Tardiff, \& Drew, 1994). High self-esteem individuals experience more positive emotions and are more active and persistent when facing difficulties, challenges, and risks (Guntersdorfer \& Golubeva, 2018). Interactions with people from different cultures might be perceived as a challenging situation. Thus, high self-esteem might be especially helpful in navigating multicultural military contexts (Rawat, 2011).

Non-kinetic involvement in a multicultural setting is becoming the norm for soldiers, and the ability to operate effectively in these environments is critical to the success of the foreign mission (McCloskey, Behymer, Papautsky, Ross, \& Abbe, 2010a) and multinational teams (Sutton \& Pierce, 2003). The contemporary operating environment is often characterized by ambiguous, multicultural contexts in which soldiers need to adapt quickly without extensive knowledge of the region or its people (McCloskey, Grandjean, Behymer, \& Ross, 2010b). At the beginning, the academic and then military communities have done considerable work, developing and discussing ways to make sense of intercultural competences in practice (Rodman, 2015). For deployed soldiers cross-cultural skills are more important than ever before. Crosscultural competence is critical to mission success, and specifically, because soldiers can no longer certainly predict where their next deployments may be, general cross-cultural competence is emerging as a critical competency in an unpredictable environment (McCloskey, Behymer, Papautsky, \& Grandjean, 2012). The ability to operate effectively in different cultures is of paramount importance to soldiers who carry out missions overseas (Brenneman, Klafehn, Burrus, Roberts, \& Kochert, 2016). Soldiers perceive cultural competence training as the next step to check during required pre-deployment training.

Cultural competence training must be embraced by the unit early on in the train-up process. Cultural awareness is a combat multiplier in a counterinsurgency environment and its importance is relative to that of combat skills training. Having cultural competence can give soldiers an advantage not only on the battlefield, but before everything else during peacekeeping operations. In a counterinsurgency environment soldiers' cultural competence is the key to success (Leslie, 2007). The population is the center of gravity in a counterinsurgency environment fight, and therefore understanding their culture and show- 
ing respect to that should be a significant factor that should be taken into account.

\section{PRESENT RESEARCH}

The relationship between personality traits and individual differences and CQ has still not been adequately researched. There is a dearth of evidence especially with regards to the new EU countries. Citizens in those countries are facing a new challenge of migration and increased migrant populations in schools, universities, and workplaces. A low level of multicultural experience in these countries, almost culturally homogeneous up until now, can become a problem in the increasingly frequent face-to-face and computer-mediated interactions with foreigners (Szulc, 2018a, 2018b). In comparison to other EU countries, citizens of countries such as Hungary, the Czech Republic, Slovakia, and Poland exhibit lower levels of acceptance towards migrants.

The aim of the present research was to establish which personality traits and which selected individual differences are related to CQ. To this end, five studies were carried out. In Study 1, the relationship between CQ and personality traits was explored in a Slovak and Polish sample. Studies 2 and 3 involved an attempt to identify which selected personality trait has the greatest impact on CQ. Study 4 focused on measuring the size and direction of the relationship between CQ and emotional intelligence. Study 5 measured the size and direction of the relationship between self-esteem and CQ. Each study involved students from technical, liberal arts, and military colleges as participants. A detailed description of each sample is presented below, together with the studies' description.

\section{PROCEDURE}

After obtaining consent from its creators, the CQ inventory was translated into Polish and Slovak by an English philologist with psychological education. Next, the inventory was back-translated into English. Finally, an experienced English philologist translated this version into Polish/Slovak. The two English translations were compared and the final version was used in the research.

\section{STUDY 1}

\section{PARTICIPANTS AND PROCEDURE}

\section{Participants}

Slovak and Polish university students took part in Study 1 . The Slovak sample comprised 74 individuals: 60 men and 14 women, mean age $=19.81, S D=1.26$.
The Polish sample comprised 71 individuals: 18 men and 53 women, mean age $=23.70, S D=2.07$.

\section{Method}

Cultural intelligence. Cultural intelligence was assessed with the 20-item, four-factor inventory developed and validated by Ang et al. (2007). The questionnaire was used with the authors' permission. The inventory includes four items for metacognitive CQ, six for cognitive CQ, five for motivational CQ, and five for behavioral CQ. Sample items include "I am conscious of the cultural knowledge I apply to cross cultural interactions" for metacognitive CQ, "I know the cultural values and religious beliefs of other cultures" for cognitive $\mathrm{CQ}$, "I am sure I can deal with the stresses of adjusting to a culture that is new to me" for motivational CQ, and "I change my nonverbal behavior when a cross-cultural situation requires it" for behavioral CQ. Participants were asked to indicate how each statement described their competences by means of a 7-point Likert scale ranging from 1 (strongly disagree) to 7 (strongly agree).

Personality. Personality was assessed with the Mini International Personality Item Pool (Mini-IPIP) Scales by Donnellan, Oswald, Baird, and Lucas (2006), in Polish adaptation by Topolewska, Skimina, Strus, Rowiński, and Cieciuch (2014). The scales are composed of five subscales: extraversion (four items, e.g., "Am the life of the party"); agreeableness (four items, e.g., "Sympathize with others' feelings"); conscientiousness (four items, e.g., "Get chores done right away"); neuroticism (four items, e.g., "Have frequent mood swings"), and intellect (four items, e.g., "Have a vivid imagination"). The participants gave their answers on a 5-point Likert scale ranging from 1 (very inaccurate) to 5 (very accurate).

\section{RESULTS}

Tables 1 and 2 show the correlations between all assessed variables in the Slovak and Polish sample, respectively.

The relationship between $\mathrm{CQ}$ and personality traits assumed different patterns depending on the participants' country of origin. In the Slovak sample, extraversion was positively related to scores on all the CQ factors to a similar level. The strongest relationship was between extraversion and motivational CQ (.39). Notably, a negative relationship between agreeableness and metacognitive CQ (-.37) also emerged. In the Polish sample, neuroticism was related to motivational CQ (.31). Also, intellect was positively related to metacognitive, cognitive, and motivational CQ (correlations from .24 to .35 ).

The obtained results differed significantly between the Slovak and the Polish samples, which made their precise interpretation considerably more difficult. Thus, subsequent studies involved only Polish samples. 
Table 1

Means, standard deviations, scale reliabilities and inter-correlations between cultural intelligence and personality dimensions (Slovak sample)

\begin{tabular}{|c|c|c|c|c|c|c|c|c|c|c|c|}
\hline Variables & M & $S D$ & $\alpha$ & 1 & 2 & 3 & 4 & 5 & 6 & 7 & 8 \\
\hline 1. Metacognitive CQ & 4.88 & 0.83 & .71 & - & & & & & & & \\
\hline 2. Cognitive $\mathrm{CQ}$ & 4.33 & 0.75 & .75 & $.40^{* *}$ & - & & & & & & \\
\hline 3. Motivational CQ & 4.79 & 1.04 & .82 & $.41^{* *}$ & $.32^{* *}$ & - & & & & & \\
\hline 4. Behavioral CQ & 4.83 & 1.10 & .87 & $.44^{* *}$ & $.32^{* *}$ & $.64^{* *}$ & - & & & & \\
\hline 5. Extraversion & 3.20 & 0.78 & .75 & $.26^{*}$ & $.31^{* *}$ & $.39^{* *}$ & $.33^{* *}$ & - & & & \\
\hline 6. Agreeableness & 2.54 & 0.80 & .78 & $-.37^{* *}$ & -.04 & -.20 & -.16 & -.22 & - & & \\
\hline 7. Conscientiousness & 2.33 & 0.67 & .71 & -.10 & .00 & -.13 & -.03 & -.01 & -.06 & - & \\
\hline 8. Neuroticism & 2.83 & 0.50 & .78 & .01 & -.16 & -.08 & -.06 & -.19 & -.06 & .05 & - \\
\hline 9. Intellect & 3.18 & 0.56 & .71 & .12 & .12 & .01 & -.10 & -.14 & -.20 & $-.24^{*}$ & .09 \\
\hline
\end{tabular}

Table 2

Means, standard deviations, scale reliabilities and inter-correlations between cultural intelligence and personality dimensions (Polish sample)

\begin{tabular}{|c|c|c|c|c|c|c|c|c|c|c|c|}
\hline Variables & $M$ & $S D$ & $\alpha$ & 1 & 2 & 3 & 4 & 5 & 6 & 7 & 8 \\
\hline 1. Metacognitive CQ & 5.07 & 1.08 & .85 & - & & & & & & & \\
\hline 2. Cognitive $\mathrm{CQ}$ & 3.98 & 1.17 & .85 & $.61^{* *}$ & - & & & & & & \\
\hline 3. Motivational CQ & 4.65 & 1.15 & .82 & $.52^{* *}$ & $.52^{* *}$ & - & & & & & \\
\hline 4. Behavioral CQ & 4.53 & 1.38 & .89 & $.33^{* *}$ & $.30^{*}$ & $.26^{*}$ & - & & & & \\
\hline 5. Extraversion & 3.24 & 1.06 & .79 & -.14 & -.10 & .11 & -.04 & - & & & \\
\hline 6. Agreeableness & 3.70 & 0.83 & .77 & -.07 & -.01 & .01 & .15 & .16 & - & & \\
\hline 7. Conscientiousness & 3.59 & 0.90 & .79 & -.04 & .03 & -.02 & -.08 & .06 & .06 & - & \\
\hline 8. Neuroticism & 2.51 & 0.88 & .71 & .15 & .15 & $.31^{* *}$ & .03 & .22 & -.17 & $.25^{*}$ & - \\
\hline 9. Intellect & 3.87 & 0.64 & .68 & $.26^{*}$ & $.24^{*}$ & $.35^{* *}$ & -.03 & .01 & .12 & .13 & $.24^{*}$ \\
\hline
\end{tabular}

Note. ${ }^{*} p<.05,{ }^{* *} p<.01$; two-tailed test.

\section{STUDY 2}

\section{PARTICIPANTS AND PROCEDURE}

\section{Participants}

One hundred and thirty-eight people took part in Study 2 (43 men and 95 women). Their mean age was 21.97, $S D=3.88$.

\section{Method}

Cultural intelligence was assessed the same way as in Study 1.

Personality. Selected personality traits were measured with scales from the International Personality Item Pool - 16 Personality Factor Questionnaire (IPIP16PF; Goldberg, 1999; in Polish adaptation by Strus,
Cieciuch, \& Rowiński, 2014). The scales of warmth (10 items, e.g., "Take time out for others"), gregariousness (10 items, e.g., "Love large parties"), and friendliness (10 items, e.g., "Feel comfortable around people") were used. Participants gave their answers on a 5-point Likert scale ranging from 1 (very inaccurate) to 5 (very accurate).

\section{RESULTS}

Descriptive statistics and correlations between all assessed variables are shown in Table 3.

There was no relationship between warmth and the individual CQ factors. Gregariousness was positively associated with metacognitive (.19) and motivational CQ (.40). Additionally, friendliness was positively associated with motivational (.41) and behavioral CQ (.26). 


\section{STUDY 3}

\section{PARTICIPANTS AND PROCEDURE}

\section{Participants}

One hundred and twenty-nine individuals took part in the study (33 men and 88 women). Their mean age was $22.33, S D=3.88$.

\section{Method}

Cultural intelligence was assessed the same way as in Study 1.

Personality. Selected personality traits were measured with scales from the IPIP-16PF (Goldberg, 1999; in Polish adaptation by Strus et al., 2014). The scales of sensitivity (10 items, e.g., "Don't like action movies"), distrust (10 items, e.g., "Believe that people seldom tell you the whole truth"), and reserve (10 items, e.g., "Reveal little about myself") were used. Participants gave their answers on a 5-point Likert scale ranging from 1 (very inaccurate) to 5 (very accurate).

\section{RESULTS}

Correlations between all variables are shown in Table 4 .

No relationships emerged between distrust and reserve and the individual CQ factors. However, sensitivity was positively associated with metacognitive (.44), cognitive (.25), and motivational (.33) CQ.

\section{STUDY 4}

\section{PARTICIPANTS AND PROCEDURE}

\section{Participants}

Seventy-four individuals took part in the study (25 men and 49 women). Their mean age was 20.23 , $S D=1.05$

Method

Cultural intelligence was assessed the same way as in Study 1.

Table 3

Means, standard deviations, scale reliabilities and inter-correlations between cultural intelligence and selected personality dimensions

\begin{tabular}{|c|c|c|c|c|c|c|c|c|c|}
\hline Variables & $M$ & $S D$ & $\alpha$ & 1 & 2 & 3 & 4 & 5 & 6 \\
\hline 1. Metacognitive CQ & 5.10 & 1.03 & .84 & - & & & & & \\
\hline 2. Cognitive CQ & 4.25 & 0.87 & .72 & $.36^{* *}$ & - & & & & \\
\hline 3. Motivational CQ & 5.09 & 1.08 & .85 & $.26^{* *}$ & $.30^{* *}$ & - & & & \\
\hline 4. Behavioral CQ & 5.16 & 0.97 & .82 & $.30^{* *}$ & $.23^{*}$ & $.39^{* *}$ & - & & \\
\hline 5. Warmth & 3.82 & 0.68 & .87 & .09 & -.01 & .09 & .05 & - & \\
\hline 6. Gregariousness & 3.48 & 0.73 & .83 & $.19^{*}$ & .00 & $.40^{* *}$ & .13 & $.41^{* *}$ & - \\
\hline 7. Friendliness & 3.35 & 0.94 & .78 & .15 & .08 & $.41^{* *}$ & $.26^{* *}$ & $.44^{* *}$ & $.72^{* *}$ \\
\hline
\end{tabular}

Note. ${ }^{*} p<.05,{ }^{* *} p<.01$; two-tailed test.

Table 4

Means, standard deviations, scale reliabilities and inter-correlations between cultural intelligence and selected personality dimensions

\begin{tabular}{|c|c|c|c|c|c|c|c|c|c|}
\hline Variables & M & $S D$ & $\alpha$ & 1 & 2 & 3 & 4 & 5 & 6 \\
\hline 1. Metacognitive CQ & 4.93 & 0.91 & .80 & - & & & & & \\
\hline 2. Cognitive CQ & 4.05 & 0.91 & .78 & $.45^{* *}$ & - & & & & \\
\hline 3. Motivational CQ & 4.92 & 1.09 & .87 & $.50^{* *}$ & $.25^{* *}$ & - & & & \\
\hline 4. Behavioral CQ & 4.79 & 1.12 & .86 & $.37^{* *}$ & $.36^{* *}$ & $.55^{* *}$ & - & & \\
\hline 5. Sensitivity & 3.51 & 0.72 & .87 & $.44^{* *}$ & $.25^{* *}$ & $.26^{* *}$ & .18 & - & \\
\hline 6. Distrust & 3.15 & 0.71 & .79 & .12 & .16 & .03 & .12 & .16 & - \\
\hline 7. Reserve & 2.95 & 0.80 & .81 & .01 & .10 & -.01 & .15 & -.00 & $.51^{* *}$ \\
\hline
\end{tabular}


Emotional intelligence. Emotional intelligence was assessed using the Emotional Intelligence Questionnaire (INTE; Schutte et al., 1998; Jaworowska \& Matczak, 2005). The INTE consists of 33 items, divided into two scales: recognizing emotions (items, e.g., "I easily recognize my emotions as I experience them") and using one's emotions effectively in the management of one's own activity or the activity of other people (items, e.g., "When I am in a positive mood, I am able to come up with new ideas"). Participants gave their answers on a 5-point Likert scale ranging from 1 (strongly disagree) to 5 (strongly agree).

\section{RESULTS}

Correlations between all variables are shown in Table 5 .

The results show that the ability to use emotions to aid thinking and action, as well as emotion recognition, was positively correlated with behavioral CQ (.33). Overall emotional intelligence was also positively related to metacognitive (.26), motivational (.23), and behavioral (.44) CQ.

\section{STUDY 5}

\section{PARTICIPANTS AND PROCEDURE}

\section{Participants}

Ninety-one individuals took part in the last study (43 men and 48 women). Their mean age was 21.93 , $S D=3.06$. Cadets of the Polish Naval Academy and students of civil universities participated in this study.

\section{Method}

Cultural intelligence was assessed the same way as in Study 1.

Self-esteem. The Rosenberg Self-Esteem Scale (SES; Rosenberg, 1989; in Polish adaptation by Łaguna, Lachowicz-Tabaczek, \& Dzwonkowska, 2007) was used to measure global self-esteem. The SES consists of 10 items (e.g., "On the whole, I am satisfied with myself"). Participants gave their answers on a 5-point Likert scale ranging from 1 (strongly agree) to 5 (strongly disagree).

Table 5

Means, standard deviations, scale reliabilities and inter-correlations between cultural intelligence and emotional intelligence

\begin{tabular}{|c|c|c|c|c|c|c|c|c|c|}
\hline Variables & M & $S D$ & $\alpha$ & 1 & 2 & 3 & 4 & 5 & 6 \\
\hline 1. Metacognitive CQ & 4.93 & 0.91 & .80 & - & & & & & \\
\hline 2. Cognitive CQ & 4.05 & 0.91 & .78 & $.45^{* *}$ & - & & & & \\
\hline 3. Motivational CQ & 4.92 & 1.09 & .87 & $.50 * *$ & $.25^{* *}$ & - & & & \\
\hline 4. Behavioral CQ & 4.79 & 1.12 & .86 & $.37^{* *}$ & $.36^{* *}$ & $.55^{* *}$ & - & & \\
\hline 5. Use emotions & 3.51 & 0.72 & .87 & $.44^{* *}$ & $.25^{* *}$ & $.26^{* *}$ & .18 & - & \\
\hline 6. Recognizing emotions & 3.15 & 0.71 & .79 & .12 & .16 & .03 & .12 & .16 & - \\
\hline 7. Emotional intelligence & 2.95 & 0.80 & .81 & .01 & .10 & -.01 & .15 & -.00 & $.51^{* *}$ \\
\hline
\end{tabular}

Note. ${ }^{*} p<.05,{ }^{* *} p<.01$; two-tailed test; Use emotions - use one's emotions effectively in the management of one's own activity or the activity of other people.

Table 6

Means, standard deviations, scale reliabilities and inter-correlations between cultural intelligence and self-esteem

\begin{tabular}{lccccccc}
\hline Variables & $M$ & $S D$ & $\alpha$ & 1 & 2 & 3 & 4 \\
\hline 1. Metacognitive CQ & 5.20 & 0.89 & .78 & - & & & \\
2. Cognitive CQ & 4.26 & 0.88 & .79 & $.50^{* *}$ & - & & \\
3. Motivational CQ & 4.60 & 1.18 & .80 & $.35^{* *}$ & $.30^{* *}$ & - & $.43^{* *}$ \\
4. Behavioral CQ & 4.73 & 1.17 & .83 & $.40^{* *}$ & $.35^{* *}$ & - \\
5. Self-esteem & 29.41 & 5.55 & .83 & -.05 & .07 & $.43^{* *}$ & .14 \\
\hline Note. ${ }^{* *} p<.01$, two-tailed test. & & & & & &
\end{tabular}


RESULTS

Correlations between all variables are shown in Table 6 .

Only a positive correlation of global self-esteem with motivational CQ (.43) emerged.

\section{DISCUSSION}

The present research was an attempt to establish the personality and individual difference correlates of CQ. The migration crisis currently underway in Europe results in the movement of large groups of people. In the UK, Germany, France, and Ireland, foreigners comprise around $14 \%$ of the population. Before the Russia-Ukraine conflict, under $2 \%$ of the population of Poland and Slovakia was foreign (Woźniakowska-Fajst, 2016). A trend of increasing numbers of foreign students and workers can also be seen in those countries. Since 2005, the number of foreign students in Poland has increased over tenfold (Długosz, 2018).

The dynamic increase in the number of foreigners is a challenge for people who, up until recently, have lived in almost monocultural societies. These people, who thus far have functioned according to uniform and traditional cultural patterns, have begun to meet people from different cultural groups increasingly often, without leaving their own countries. Citizens of the Visegrád Group countries (Hungary, the Czech Republic, Poland, Slovakia) do not hold positive views about the increased number of migrants (CBOS, 2015).

The present research, representing a multicultural approach, aimed to identify the personality and individual difference correlates of CQ. In the Slovak sample, extraversion was positively related to all the CQ factors. Cultural intelligence thus increases with extraversion, which is likely a result of greater interpersonal contacts and experiences. This result is in line with the results of Huff, Song, and Gresch (2014) in a sample of Japanese students. There was no correlation between extraversion and CQ in the Polish sample. However, an interesting result is the negative relationship between agreeableness and metacognitive CQ in the Slovak sample. In the original research by Ang et al. (2007), no correlation of agreeableness with any of the CQ factors was reported. One explanation of this discrepancy might involve the characteristics of the sample, namely, students (predominantly male) of the Armed Force Academy. Neuroticism was positively related to motivational CQ among Polish students. Motivational CQ, that is, the ability to direct and sustain energy towards solving intercultural problems, increases together with neuroticism. It may be that emotionally sensitive people have greater motivation to invest effort into building intercultural contacts.
Intellect was positively correlated with metacognitive, cognitive, and motivational CQ in the Polish sample. This result was similar to those obtained by Devin (2017) in a sample of Persian sports coaches. Individuals high in openness to experience are characterized by high knowledge and understanding of cultural processes. Their knowledge can result both from experience as well as from directed cognitive activity. Such individuals also display an aboveaverage ability to direct their attention and energy towards knowing and understanding multicultural situations (Barzykowski, Majda, Szkup, \& Przyłęcki, 2019).

Studies 2 and 3 were carried out in order to search for more precise personality factors related to CQ. They revealed that gregariousness and friendliness are positively associated with motivational CQ. A positive social orientation facilitates high effectiveness in interpersonal contacts, including with people from different cultures. It is also interesting that warmth was not related to any of the CQ factors. High sensitivity was related to high metacognitive, cognitive, and motivational CQ. This relationship is probably similar to the one between neuroticism and CQ. Higher sensitivity translates into an individualized approach, empathy, and motivation towards maintaining the conversation partner's wellbeing. No relationship between distrust and reserve and the CQ factors was revealed. Individuals both high and low in distrust and reserve are characterized by similar levels of CQ. Socially positive personality traits (i.e., gregariousness, friendliness, and sensitivity) are related to various aspects and manifestations of CQ. Because research on CQ has begun relatively recently, little reference to previous studies can be made.

Study 4 points towards a relationship between $\mathrm{CQ}$ and emotional intelligence (Barzykowski et al., 2019; Daryani, Aali, Amini, \& Shareghi, 2017; Jonck $\&$ Swanepoel, 2015). Moon (2010) claims that specific factors of emotional intelligence are related to specific factors of CQ. Individuals who recognize and use their emotions effectively are also characterized by higher levels of CQ, as displayed in their behaviors. Emotional intelligence allows for effective and satisfying social functioning, not only in contacts with people from the same culture (Darvishmotevali et al., 2018). Emotional and cultural intelligence are not identical constructs, though they are both aspects of social intelligence (Kumar, Rose, \& Subramaniam, 2008).

Study 5 showed that self-esteem is only related to motivational CQ. Similar conclusions are presented by Barzykowski et al. (2019), although in this case, there are also no previous studies with which to make comparisons.

Additional comparisons were made of cadets of the Polish Naval Academy and students of civilian universities (not included in the tables). No differ- 
ences were found in terms of cultural intelligence between these groups. So far, little research has been done on the cultural competence of soldiers. Abbe, Geller, and Everett (2010) found that officers have a higher level of intercultural development than noncommissioned officers.

Concluding the presented research, it must be underscored that people from similar, almost culturally identical countries such as Poland and Slovakia differ with respect to the relationships between personality factors and CQ. Selected personality factors and individual differences are related to $\mathrm{CQ}$, although this relationship is not fully explored. Considering the societal changes resulting from large-scale migration and the increased frequency of interactions between different cultural groups in many situations, the question of intercultural contact will increase in importance (Szrajda et al., 2019).

\section{REFERENCES}

Abbe, A., Geller, D. S., \& Everett, S. L. (2010). Measuring cross-cultural competence in soldiers and cadets: a comparison of existing instruments. Fort Belvoir, VA: United States Army Research Institute for the Behavioral and Social Sciences.

Ang, S., Van Dyne, L., \& Koh, C. (2006). Personality correlates of the four-factor model of cultural intelligence. Group \& Organization Management, 31, 100123. https://doi.org/10.1177/1059601105275267

Ang, S., Van Dyne, L., Koh, C., Ng, K., Templer, K., Tay, C., \& Chandrasekar, N. (2007). Cultural intelligence: Its measurement and effects on cultural judgment and decision making, cultural adaptation and task performance. Management and Organization Review, 3, 335-371. https://doi. org/10.1111/j.1740-8784.2007.00082.x

Ang, S., \& Van Dyne, L. (2008). Conceptualization of cultural intelligence: Definition, distinctiveness, and nomological network. In S. Ang \& L. Van Dyne (Eds.), Handbook of cultural intelligence: Theory, measurement, and applications (pp. 3-15). Armonk, NY: M. E. Sharpe.

Barzykowski, K., Majda, A., Szkup, M., \& Przyłęcki, P. (2019). The Polish version of the Cultural Intelligence Scale: Assessment of its reliability and validity among healthcare professionals and medical faculty students. PLoS One, 14, 1-22. https://doi. org/10.1371/journal.pone.0225240

Barrick, M. R., \& Mount, M. K. (1991). The Big Five personality dimensions and job performance: a meta-analysis. Personnel Psychology, 44, 1-26. https://doi.org/10.1111/j.1744-6570.1991.tb00688.x

Battistich, V., Solomon, D., \& Delucchi, K. (1993). Interaction processes and student outcomes in $\mathrm{co}^{-}$ operative learning groups. The Elementary School Journal, 94, 19-32. https://doi.org/10.1086/461748
Bishop, J. A., \& Inderbitzen, H. M. (1995). Peer acceptance and friendship: an investigation of their relation to self-esteem. Journal of Early Adolescence, 15, 476-489. https://doi.org/10.1177/02724316950 15004005

Borecka-Biernat, D. (2014). The role of self-assessment and emotions in designation of an aggressive strategy of coping with a social conflict situation by gymnasium school students. Current Issues in Personality Psychology, 2, 17-29. https:// doi.org/10.5114/cipp.2014.43098

Brenneman, M.W., Klafehn, J., Burrus, J., Roberts, R. D., \& Kochert, J. (2016). Assessing cross-cultural competence: a working framework and prototype measures for use in military contexts. In J. L. Wildman, R. L. Griffith, \& B. K. Armon (Eds.), Critical issues in cross cultural management (pp. 103-131). New York: Springer International Publishing.

Brown, J. D., \& Dutton, K. A. (1997). Global self-esteem and specific self-views as determinants of people's reactions to success and failure. Journal of Personality and Social Psychology, 73, 139-148. https://doi.org/10.1037/0022-3514.73.1.139

Buss, D. M. (2009). How can evolutionary psychology successfully explain personality and individual differences? Perspectives on Psychological Science, 4, 359-366. https://doi.org/10.1111/j.17456924.2009.01138.x

CBOS (2015). Stosunek do imigrantów w krajach Grupy Wyszehradzkiej [Attitude to immigrants in the Visegrad Group countries]. Warszawa: Fundacja Centrum Badania Opinii Społecznej.

Costa, P. T., Jr, \& McCrae, R. R. (1992). Four ways five factors are basic. Personality and Individual Differences, 13, 653-665. https://doi.org/10.1016/01918869(92)90236-I

Costa, P. T., \& McCrae, R. R. (1995). Domains and facets: Hierarchical personality assessment using the Revised NEO Personality Inventory. Journal of Personality Assessment, 64, 21-50. https://doi.org/ 10.1207/s15327752jpa6401_2

da Costa, S., Páez, D., Sánchez, F., Garaigordobil, M., \& Gondim, S. (2015). Personal factors of creativity: a second order meta-analysis. Revista de Psicología Del Trabajo y de Las Organizaciones, 31, 165-173. https://doi.org/10.1016/j.rpto.2015.06.002

Darvishmotevali, M., Altinay, L., \& De Vita, G. (2018). Emotional intelligence and creative performance: Looking through the lens of environmental uncertainty and cultural intelligence. International Journal of Hospitality Management, 73, 44-54. https:// doi.org/10.1016/j.ijhm.2018.01.014

Daryani, S. M., Aali, S., Amini, A., \& Shareghi, B. (2017). A comparative study of the impact of emotional, cultural, and ethical intelligence of managers on improving bank performance. International Journal of Organizational Leadership, 6, 197-210. https://doi.org/10.33844/ijol.2017.60318 
Depaula, D. P., \& Azzollini, C. S. (2013). Analysis of the big five model of personality as a predictor of cultural intelligence. Psiencia: Revista Latinoamericana de Ciencia Psicológica, 5, 35-43. https://doi. org/10.5872/psiencia/5.1.24

Depaula, P. D., Azzollini, S. C., Cosentino, A. C., \& Castillo, S. E. (2016). Personality, character strengths and cultural intelligence: "Extraversion" or "openness" as further factors associated to the cultural skills? Avances En Psicología Latinoamericana, 34, 415-436. https://doi.org/10.12804/apl34.2.2016.13

Devin, H. F. (2017). Investigating the relationship between Big Five personality traits and cultural intelligence on football coaches. Human \& Social Studies, 6, 116-131. https://doi.org/10.1515/hssr2017-0027

Długosz P. (2018). Integration of Ukrainian students in Poland. Migration Studies - Review of Polish Diaspora, 2, 67-92. https://doi.org/10.4467/25444972 SMPP.18.020.9146

Donnellan, M. B., Oswald, F. L., Baird, B. M., \& Lucas, R. E. (2006). The Mini-IPIP Scales: Tiny-yeteffective measures of the Big Five factors of personality. Psychological Assessment, 18, 192-203. https://doi.org/10.1037/1040-3590.18.2.192

Earley, P. C. (2002). Redefining interactions across cultures and organizations: Moving forward with cultural intelligence. Research in Organizational Behavior, 24, 271-299. https://doi.org/10.1016/ s0191-3085(02)24008-3

Earley, P. C., \& Ang, S. (2003). Cultural intelligence: Individual interactions across cultures. Stanford, CA: Stanford University Press.

Fischer, R. (2011). Cross-cultural training effects on cultural essentialism beliefs and cultural intelligence. International Journal of Intercultural Relations, 35, 767-775. https://doi.org/10.1016/j.ijintrel.2011.08.005

Goldberg, L. R. (1999). A broad-bandwidth, public domain, personality inventory measuring the lower-level facets of several five-factor models. In I. Mervielde, I. Deary, F. De Fruyt, \& F. Ostendorf (Eds.), Personality psychology in Europe (Vol. 7, pp. 7-28). Tilburg: Tilburg University Press.

Guntersdorfer, I., \& Golubeva, I. (2018). Emotional intelligence and intercultural competence: Theoretical questions and pedagogical possibilities. Intercultural Communication Education, 1, 54-63. https://doi.org/10.29140/ice.v1n2.60

Heimpel, S. A., Wood, J. V., Marshall, M. A., \& Brown, J. D. (2002). Do people with low selfesteem really want to feel better? Self-esteem differences in motivation to repair negative moods. Journal of Personality and Social Psychology, 82, 128-147. https://doi.org/10.1037/0022-3514.82.1.128

Huff, K. C., Song, P., \& Gresch, E. B. (2014). Cultural intelligence, personality, and cross-cultural adjustment: a study of expatriates in Japan. Inter- national Journal of Intercultural Relations, 38, 151157. https://doi.org/10.1016/j.ijintrel.2013.08.005

Imai, L., \& Gelfand, M. J. (2010). The culturally intelligent negotiator: The impact of cultural intelligence (CQ) on negotiation sequences and outcomes. Organizational Behavior and Human Decision Processes, 112, 83-98. https://doi.org/10.1016/j.obhdp. 2010.02.001

Jaworowska, A., \& Matczak, A. (2005). Kwestionariusz Inteligencji Emocjonalnej INTE N. S. Schutte, J. M. Malouffa, L. E. Hall, D. J. Haggerty'ego, J. T. Cooper, C. J. Goldena, L. Dornheim. Podręcznik [INTE. Emotional Intelligence Questionnaire by N. S. Schutte, J. M. Mallouff, L. E. Hall, D. J. Haggerty, J. T. Cooper, C. J. Golden, L. Dornheim. Manual]. Warszawa: Pracownia Testów Psychologicznych PTP.

Jonck, P., \& Swanepoel, E. (2015). Exploring the theoretical link between cultural and emotional intelligence: a system analysis for human resource management. South African Journal of Business Management, 46, 77-83. https://doi.org/10.4102/ sajbm.v46i4.111

Kumar, N., Rose, R. C., \& Subramaniam, S. S. (2008). The bond between intelligences: Cultural, emotional, and social. Performance Improvement, 47, 42-48. https://doi.org/10.1002/pfi.20039

Lakey, B., Tardiff, T. A., \& Drew, J. B. (1994). Negative social interactions: Assessment and relations to social support, cognition, and psychological distress. Journal of Social and Clinical Psychology, 13, 42-62. https://doi.org/10.1521/jscp.1994.13.1.42

Leslie, M. S. (2007). Integrating cultural sensitivity into combat operations. Armor, 116, 35-38.

Li, M., Mobley, W. H., \& Kelly, A. (2016). Linking personality to cultural intelligence: an interactive effect of openness and agreeableness. Personality and Individual Differences, 89, 105-110. https://doi. org/10.1016/j.paid.2015.09.050

Lie, D., Suyasa, P. T., \& Wijaya, E. (2016). The mediating role of cultural intelligence in the relationship between the openness to experience personality trait and job satisfaction among expatriates. Makara - Human Behavior Studies in Asia, 20, 46-56. https://doi.org/10.7454/mssh.v20i1.3486

Lin, Y., Chen, A. S., \& Song, Y. (2012). Does your intelligence help to survive in a foreign jungle? The effects of cultural intelligence and emotional intelligence on cross-cultural adjustment. International Journal of Intercultural Relations, 36, 541552. https://doi.org/10.1016/j.ijintrel.2012.03.001

Łaguna, M., Lachowicz-Tabaczek, K., \& Dzwonkowska, I. (2007). Skala samooceny SES Morrisa Rosenberga - polska adaptacja metody [The Rosenberg Self-Esteem Scale: Polish adaptation of the scale]. Psychologia Spoteczna, 2, 164-176.

MacDonald, K. (1998). Evolution, culture, and the Five-Factor Model. Journal of Cross-Cultural 
Psychology, 29, 119-149. https://doi.org/10.1177/ 0022022198291007

Mandal, E., \& Latusek, A. (2018). Love attitudes, psychological femininity and masculinity, Machiavellianism, narcissism, and emotional intelligence of rejectors in close relationships. Current Issues in Personality Psychology, 6, 188-199. https://doi. org/10.5114/cipp.2018.75647

McCloskey, M. J., Behymer, K. J., Papautsky, E. L., \& Grandjean, A. (2012). Measuring learning and development in cross-cultural competence. Fort Belvoir, VA: United States Army Research Institute for the Behavioral and Social Sciences.

McCloskey, M. J., Behymer, K. J., Papautsky, E. L., Ross, K. G., \& Abbe, A. (2010a). A developmental model of cross-cultural competence at the tactical level. Fort Belvoir, VA: United States Army Research Institute for the Behavioral and Social Sciences.

McCloskey, M. J., Grandjean, A., Behymer, K. J., \& Ross, K. (2010b). Assessing the development of cross-cultural competence in soldiers. Fort Belvoir, VA: United States Army Research Institute for the Behavioral and Social Sciences.

McCrae, R. R., \& Costa, P. T. (1995). Trait explanations in personality psychology. European Journal of Personality, 9, 231-252. https://doi.org/10.1002/ per.2410090402

Mol, S. T., Born, M. P., Willemsen, M. E., \& Van Der Molen, H. T. (2005). Predicting, expatriate job performance for selection purposes: a quantitative review. Journal of Cross-Cultural Psychology, 36, 590620. https://doi.org/10.1177/0022022105278544

Moon, T. (2010), Emotional intelligence correlates of the four-factor model of cultural intelligence. Journal of Managerial Psychology, 25, 876-898. https://doi.org/10.1108/02683941011089134

Moroń, M. (2018). Perceived emotional intelligence and life satisfaction: the mediating role of the positivity ratio. Current Issues in Personality Psychology, 6, 212-223. https://doi.org/10.5114/cipp.2018. 75650

Peltokorpi, V. (2008). Cross-cultural adjustment of expatriates in Japan. The International Journal of $\mathrm{Hu}^{-}$ man Resource Management, 19, 1588-1606. https:// doi.org/10.1080/09585190802294903

Piotrowski, A. (2018). Samoocena stanu zdrowia, wypadki w trakcie służby i profilaktyka stresu zawodowego w Służbie Więziennej [Self-evaulation of personal physical health, accidents while performing duty and preventive treatment of stress in Prison Service]. Medycyna Pracy, 69, 425-438. https://doi.org/10.13075/mp.5893.00535

Presbitero, A. (2016). Cultural intelligence (CQ) in virtual, cross-cultural interactions: Generalizability of measure and links to personality dimensions and task performance. International Journal of Intercultural Relations, 50, 29-38. https://doi.org/10.1016/j. ijintrel.2015.11.001
Rawat, S. (2011). Enhancing self-esteem of the soldier. Journal of Defense Studies, 5, 122-137.

Rockstuhl, T., Seiler, S., Ang, S., Van Dyne, L., \& Annen, H. (2011). Beyond general intelligence (IQ) and emotional intelligence (EQ): The role of cultural intelligence (CQ) on cross-border leadership effectiveness in a globalized world. Journal of Social Issues, 67, 825-840. https://doi.org/10.1111/j.15404560.2011.01730.x

Rodman, J. (2015). Cross-cultural competence: Introduction and overview of key concepts. Fort Leavenworth, KS: Human Dimension Capabilities Development Task Force.

Rosenberg, M. (1965). Society and adolescent self-image. New York: Princeton University Press.

Rosenberg, M. (1989). Society and adolescent self-image. Revised edition. Middletown: Wesleyan University Press.

Şahin, F., Gurbuz, S., \& Köksal, O. (2014). Cultural intelligence $(\mathrm{CQ})$ in action: The effects of personality and international assignment on the development of CQ. International Journal of Intercultural Relations, 39, 152-163. https://doi.org/10.1016/j. ijintrel.2013.11.002

Schutte, N. S., Malouff, J. M., Hall, L. E., Haggerty, D. J., Cooper, J. T., Golden, C. J., \& Dornheim L. (1998). Development and validation of a measure of emotional intelligence. Personality and Individual Differences, 25, 167-177. https://doi.org/10.1016/ S0191-8869(98)00001-4

Shaffer, M. A., Harrison, D. A., Gregerson, H., Black, J. S., \& Ferzandi, L. A. (2006). You can take it with you: Individual differences and expatriate effectiveness. Journal of Applied Psychology, 91, 109125. https://doi.org/10.1037/0021-9010.91.1.109

Shu, F., McAbee, S. T., \& Ayman, R. (2017). The HEXACO personality traits, cultural intelligence, and international student adjustment. Personality and Individual Differences, 106, 21-25. https://doi. org/10.1016/j.paid.2016.10.024

Sousa, C., \& Gonçalves, G. (2017). Expatriates and non-expatriates: Effects of cultural intelligence and multicultural personality on passion for work and satisfaction with life. Psychological Thought, 10, 90-108. https://doi.org/10.5964/psyct.v10i1.197

Strus, W., Cieciuch, J., \& Rowiński, T. (2014). Circumplex structure of personality traits measured with the IPIP-45AB5C questionnaire in Poland. Personality and Individual Differences, 71, 77-82. https:// doi.org/10.1016/j.paid.2014.07.018

Sutton, J. L., \& Pierce, L. G. (2003). A framework for understanding cultural diversity in cognition and teamwork. Paper presented at the 8th International Command and Control Research Technology Symposium, Washington, DC.

Sygit-Kowalkowska, E., Sygit, K., \& Sygit, M. (2015). Emotional intelligence vs. health behaviour in selected groups in late adulthood. Annals of Agri- 
cultural and Environmental Medicine, 22, 338-343. https://doi.org/10.5604/12321966.1152092

Szczygieł, D., \& Weber, J. (2017). Emotional intelligence predicts peer-rated social competence above and beyond personality traits. Current Issues in Personality Psychology, 5, 91-101. https://doi.org/ 10.5114/cipp.2017.64490

Szrajda, J., Sygit-Kowalkowska, E., Weber-Rajek, M., Tudorowska, M., Ziółkowski, M., \& Borkowska, A. (2019). Working with socially maladjusted youths and children with developmental disorders. predictors and correlations of health among personnel in youth centres. Journal of Education Culture and Society, 10, 155-169. https://doi.org/10.15503/ jecs20191.155.169

Szulc, M. (2018a). Psychologiczne uwarunkowania, konsekwencje i przeciwdziałanie zjawisku cyberprzemocy [Psychological conditions, consequences and counteracting cyberbullying]. Wychowanie Na Co Dzień, 5/6, 272-273.

Szulc, M. (2018b). Sposoby radzenia sobie ze stresem i umiejscowienie poczucia kontroli u ofiar cyberprzemocy [Coping with stress and locus of control in cybervictims]. Pomeranian Journal of Life Sciences, 64, 127-133. https://doi.org/10.21164/pomjlifesci.449

Topolewska, E., Skimina, E., Strus, W., Rowiński, T., \& Cieciuch, J. (2014). Krótki kwestionariusz do pomiaru Wielkiej Piątki IPIP-BFM-20 [The short IPIPBFM-20 questionnaire for measuring the Big Five]. Roczniki Psychologiczne, 27, 367-384.

Thompson, R. (2018). A qualitative phenomenological study of emotional and cultural intelligence of international students in the United States of America. Journal of International Students, 8, 1220 1255. https://doi.org/10.5281/zenodo. 1250423

Woźniakowska-Fajst, D. (2016). Cudzoziemcy jako sprawcy poważnych przestępstw w Polsce - raport z badań [Foreigners as perpetrators of serious crimes in Poland - research report]. Rozprawy Spoteczne, 1, 44-56. 